\title{
A Specific Transport System for Manganese in the Filamentous Fungus Aspergillus niger
}

\author{
By STEFAN HOCKERTZ, $†$ JAN SCHMID AND GEORG AULING* \\ Institut für Mikrobiologie der Universität Hannover, Schneiderberg 50, D 3000 Hannover, FRG
}

(Received 7 April 1987; revised 26 July 1987)

The existence of energy-dependent $\mathrm{Mn}^{2+}$ influx in Aspergillus niger ATCC 11414 was demonstrated both with mycelia grown for production of citric acid and in resting mycelia suspended in 'Good'-buffers. A specific high-affinity transport system was detected at submicromolar concentrations of ${ }^{54} \mathrm{Mn}^{2+}$ which functioned independently of the transport of $\mathrm{Mg}^{2+}$ and $\mathrm{Ca}^{2+}$, but was preferentially inhibited by $\mathrm{Zn}^{2+}, \mathrm{Cu}^{2+}, \mathrm{Cd}^{2+}$. The rate of $\mathrm{Mn}^{2+}$ transport was suboptimal in the citric acid production medium (pH 3.8 or lower) as the pH optimum was found to be 5.6 in the buffer experiments.

\section{INTRODUCTION}

Evidence for $\mathrm{Mn}^{2+}$ as an important regulator of metabolism has been obtained both in fungi (Williams, 1982; Garraway \& Evans, 1984) and in bacteria such as Bacillaceae (Silver \& Jasper, 1977), Coryneform (Auling, 1983; Plönzig \& Auling, 1987) and certain lactic acid bacteria (Archibald, 1986). The question arises as to how the $\mathrm{Mn}^{2+}$ essential for these organisms can be acquired by them, as there is usually a great excess of $\mathbf{M g}^{2+}$ in normal growth media. Several energy-dependent $\mathbf{M n}^{2+}$-specific transport systems have been demonstrated in bacteria (Silver, 1978) and have also been reported for eukaryotes like Euglena gracilis and human KB cells (Silver \& Jasper, 1977). So far no specific $\mathbf{M n}^{2+}$ transporter and very few energy-dependent influx systems for other divalent cations of the transition metals have been reported for filamentous fungi such as Neocosmospora vasinfecta (Paton \& Budd, 1972); Neurospora crassa (Mohan et al., 1984) and Aspergillus parasiticus (Failla \& Niehaus, 1986), obviously due to difficulties encountered with transport assays with mycelial growth.

More attention has been paid to yeasts and yeast-like fungi which possess energy-dependent influx systems for various metal ions. The relatively non-specific divalent cation transport system in Saccharomyces cerevisiae (Borst-Pauwels, 1981) contrasts with the more specific uptake systems observed in Candida utilis (Failla et al., 1976; Parkin \& Ross, 1985). A specific $\mathrm{Mn}^{2+}$ transporter has recently been demonstrated in this yeast (Parkin \& Ross, 1986).

The rationale behind the present study was that energy-linked transporters which exhibit both high affinity and high specificity are generally detected only in cells grown at very low metal concentrations, which presumably induce such pathways. Recently we have observed that growing Aspergillus niger in the mineral medium of Shu \& Johnson (1948) for production of citric acid induces typical symptoms of $\mathrm{Mn}^{2+}$ deficiency such as altered morphology and inhibition of DNA formation within $24 \mathrm{~h}$ of inoculation with spores (Hockertz et al., 1987). Therefore such $\mathrm{Mn}^{2+}$-depleted mycelia, from the early growth phase, should be used for examination of the uptake of $\mathrm{Mn}^{2+}$ by A. niget both in the citric acid production medium and after resuspension in 'Good'-buffers.

t Present address: Fraunhofer Institut für Toxikologie und Aerosolforschung, Nikolai-Fuchs-Str. 1, D 3000 Hannover 61, FRG.

Abbreviation: CCCP, Carbonyl cyanide $m$-chlorophenylhydrazone. 


\section{METHODS}

Organism and grow'th. The wild-type A. niger A TCC 11414, better known as A. niger Wisconsin 72-4 (Clark et al., 1966), was obtained from Dr W. Ahrens (Joh. A. Benckiser GmbH, Ludwigshafen, FRG) and maintained on yeast agar $\left(1^{-1}: 4 \mathrm{~g}\right.$ yeast extract, $10 \mathrm{~g}$ malt extract. $4 \mathrm{~g}$ glucose and $20 \mathrm{~g}$ agar $)$. Cultures $(50 \mathrm{ml})$ were grown in baffled Erlenmeyer flasks in the mineral medium of Shu \& Johnson (1948) which contained (1-1): $2 \cdot 5 \mathrm{~g} \mathrm{KH}_{2} \mathrm{PO}_{4}$; $0.25 \mathrm{~g} \mathrm{MgSO}_{4} .7 \mathrm{H}_{2} \mathrm{O} ; 2.5 \mathrm{~g} \mathrm{NH}_{4} \mathrm{NO}_{3}: 0.24 \mathrm{mg} \mathrm{CuSO}_{4} .5 \mathrm{H}_{2} \mathrm{O}: 1.1 \mathrm{mg} \mathrm{ZnSO} .7 \mathrm{H}_{2} \mathrm{O} ; 1.24 \mathrm{mg} \mathrm{FeCl}_{3} .6 \mathrm{H}_{2} \mathrm{O}$ ( $\mathrm{pH}=3.8$ ). supplemented with $14 \%(\mathrm{w} / \mathrm{v})$ sucrose.

The cultures were inoculated with $10^{5}$ conidia $\mathrm{ml}^{-1}$ and incubated at $27^{\circ} \mathrm{C}$ with shaking (250 r.p.m.). Commercial-grade sucrose was purified by passage through a cation-exchange resin (Chelex 100, Bio-Rad no. 1422852). All glassware, including that used for uptake experiments, was treated with hot nitric acid to remove contaminating trace elements. Determination of biomass as well as of sucrose or citrate in the culture filtrate was done as described by Hockertz et al. (1987).

(hemicals. Carbonyl cyanide $m$-chlorophenylhydrazone (CCCP) was obtained from Calbiochem-Behring. Antimycin A. HEPES. MES and PIPES were supplied by Sigma. Myxothiazol was a kind gift of H. Reichenbach (Gesellschaft für Biotechnologische Forschung mbH, Braunschweig-Stöckheim, FRG). Standard chemicals were obtained from Merck

Liptake of $\mathrm{Mn}^{2+}$. Uptake by growing mycelia was examined in the citric acid production medium of Shu \& Johnson (1948). Cultures from the early-exponential phase were used for the uptake experiments when a cell mass of $1.2 \mathrm{~g} \mathrm{dry} \mathrm{wt} \mathrm{I}^{-1}$ was reached after $24 \mathrm{~h}$ growth. For assays with growing mycelia $10 \mathrm{ml}$ portions were transferred to $100 \mathrm{ml}$ baffled Erlenmeyer flasks for further incubation at $27^{\circ} \mathrm{C}$ and 200 r.p.m. on a model $\mathrm{G} 76$ gyratory water bath shaker. No significant delay of growth was induced by this transfer from the main culture to the smaller volume of the uptake assay. The biomass increased from 1.2 to $1.37 \mathrm{~g}^{-1}$ within the $2 \mathrm{~h}$ duration of the uptake experiments, indicating that the $\mathrm{Mn}^{2+}$-depleted culture of $A$. niger had the same generation time $(14.3 \mathrm{~h})$ in the uptake vessel as in the main culture.

For uptake experiments with resting mycelia, cultures were grown under $\mathrm{Mn}^{2+}$ depletion as above for $24 \mathrm{~h}$. Portions $(10 \mathrm{ml})$ were washed by two low-speed centrifugations (10 min, $1100 \mathrm{~g}$ at room temperature). The residual pellets were resuspended to the original volume in the appropriate buffer (Good et al., 1966) each time, as indicated in the text. For energization of the cells the buffer contained $14 \%(w / v)$ sucrose (purified to remove traceelements as above) unless otherwise stated. De-energization was achieved either by omitting sucrose or flushing the uptake vessels with nitrogen. The experimental format above was used for the uptake assays.

Both growing and resting mycelia were allowed to equilibrate for 20 min before adding $\mathrm{Mn}^{2+}$. The inhibitor CCCP and the uncoupler 2,4-dinitrophenol (DNP) were added to growing mycelia simultaneously with $\mathrm{Mn}^{2+}$. The respiration inhibitors antimycin $\mathrm{A}$ and myxothiazol were added to resting mycelia simultaneously with $\mathrm{Mn}^{2+}$. For the competition experiments solutions of the chloride salts of $\mathrm{Mg}^{2+}, \mathrm{Ca}^{2+}, \mathrm{Co}^{2+}, \mathrm{Ni}^{2+}, \mathrm{Fe}^{2+}, \mathrm{Zn}^{2+}, \mathrm{Cu}^{2+}, \mathrm{Cd}^{2+}$ and $\mathrm{Mn}^{2+}$ were added to the uptake vessels $1 \mathrm{~min}$ before the addition of $\mathrm{Mn}^{2+}$ to give a final concentration as indicated in Table 1.

${ }^{54} \mathrm{MnCl}_{2}$ (Amersham, specific activity $100 \mu \mathrm{Ci} \mu \mathrm{g}^{-1}, 3.7 \mathrm{MBq} \mu \mathrm{g}^{-1}$ ) was added to give a final ${ }^{54} \mathrm{Mn}^{2+}$ concentration of $1.85 \mathrm{pmol} \mathrm{ml}^{-1}$ unless otherwise stated. All sampling was done with Gilson pipettes using disposable tips which were cut to widen the opening sufficiently for sucking of the mycelial portions. In our system the use of young $\mathrm{Mn}^{2+}$-depleted mycelia, harvested $1 \mathrm{~d}$ after germination, yielded suspensions homogeneous enough for uptake experiments (see Results).

At the beginning and the end of each experiment $0.1 \mathrm{ml}$ samples were pipetted into vials for determination of total radioactivity within the culture. ${ }^{54} \mathrm{Mn}^{2+}$ was counted using a $12 \mathrm{SW} / 3 \mathrm{aW} 3$ sodium iodide crystal with a $\mathrm{RCA}$ multiplier (Harshaw Chemie) and a LP 4840 Nokia Multichannel Pulse Analyzer. Counting efficiency was $21 \%$ for ${ }^{5+} \mathrm{Mn}$ (c.p.m./d.p.m.). Binding of ${ }^{54} \mathrm{Mn}^{2+}$ to filters was about $0.05 \%$ of the total radioactivity added to the uptake vessels. The amount of unspecific binding to the cell surface was calculated by determination of the ${ }^{5+} \mathrm{Mn}^{2+}$ content of cell samples at the beginning of the experiment. It was subtracted from the radioactivity contained in each cell sample to obtain uptake by cells unless otherwise stated.

\section{RESULTS}

\section{$\mathrm{Mn}^{2+}$ uptake by growing mycelia}

Uptake of $\mathrm{Mn}^{2+}$ by exponentially growing $A$. niger cultures undisturbed by any manipulations or washing procedures was examined initially. As it is difficult to determine with precision the very low manganese content in the citric acid production medium, we took the observation of inhibited DNA synthesis (Hockertz et al., 1987) as evidence that manganese deficiency was fully achieved. An abnormal morphology with short, thickened hyphae which aggregated to small spherical pellets (about $0.2 \mathrm{~mm}$ diameter) was induced in $A$. niger by $\mathrm{Mn}^{2+}$ deficiency. Such 


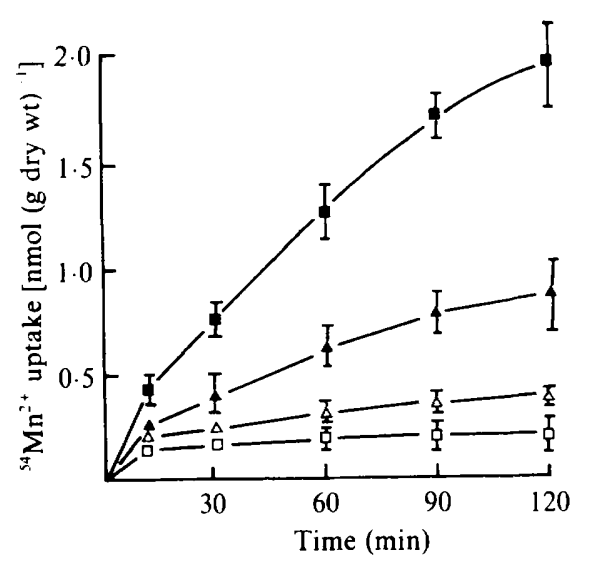

Fig. 1. Effects of inhibitors on $\mathbf{M n}^{2+}$ uptake in growing mycelia of A. niger. Values are corrected for growth during the uptake experiment, but not for specific binding to the cell surface. $\square, \mathrm{Mn}^{2+}$ uptake in the absence of DNP; $\triangle$, uptake in the presence of $1 \mathrm{mM-DNP} ; \triangle$, uptake in the presence of $10 \mathrm{mM}$ DNP; $\square$, uptake at $4^{\circ} \mathrm{C}$. The values shown are the mean \pm SE of three experiments.

Table 1. Effect of divalent cation competition on ${ }^{54} M n^{2+}$ uptake by (a) growing or (b) resting mycelia of Aspergillus niger

Values shown (mean \pm range of two experiments) are for uptake after $30 \mathrm{~min}$ in the presence of competing cation as indicated. The control value for uptake in the absence of any competing cation was $10.75 \pm 0.95 \mathrm{nmol} \mathrm{Mn}^{2+}(\mathrm{g} \text { dry } \mathrm{wt})^{-1}$. ND, not determined.

\begin{tabular}{|c|c|c|c|c|}
\hline \multirow{3}{*}{$\begin{array}{l}\text { Competing } \\
\text { cation }\end{array}$} & & \multicolumn{3}{|c|}{${ }^{54} \mathrm{Mn}^{2+}$ uptake (percentage of control) } \\
\hline & \multirow{2}{*}{$\begin{array}{l}\text { Final } \\
\text { cation } \\
\text { concn }\end{array}$} & \multicolumn{2}{|c|}{$\begin{array}{l}\text { (a) in Mineral medium } \\
(\mathrm{pH} \mathrm{3.8)}+14 \% \text { sucrose }\end{array}$} & \multirow{2}{*}{$\begin{array}{c}(b) \text { in MES buffer } \\
\text { (pH 5.6) }+14 \% \text { sucrose } \\
10 \mu \mathrm{M}\end{array}$} \\
\hline & & $1 \mathrm{mM}$ & $10 \mu \mathrm{M}$ & \\
\hline $\mathrm{Mg}^{2+}$ & & $100 \pm 5$ & ND & $100 \pm 5$ \\
\hline $\mathrm{Ca}^{2+}$ & & $94 \pm 5$ & ND & $92 \pm 4$ \\
\hline $\mathrm{Co}^{2+}$ & & $60 \pm 4$ & ND & $63 \pm 2$ \\
\hline $\mathrm{Ni}^{2+}$ & & $51 \pm 2$ & ND & $47 \pm 2$ \\
\hline $\mathrm{Fe}^{2+}$ & & $35 \pm 3$ & $80 \pm 4$ & $36 \pm 2$ \\
\hline $\mathrm{Zn}^{2+}$ & & $15 \pm 4$ & $70 \pm 3$ & $6 \pm 2$ \\
\hline $\mathrm{Cu}^{2+}$ & & $5 \pm 1$ & $50 \pm 3$ & $6 \pm 1$ \\
\hline $\mathrm{Cd}^{2+}$ & & $1 \pm 0$ & $30 \pm 1$ & $5 \pm 1$ \\
\hline $\mathrm{Mn}^{2+}$ & & $4 \pm 1$ & ND & $3 \pm 0$ \\
\hline
\end{tabular}

$\mathrm{Mn}^{2+}$ depleted mycelia were metabolically active and could be handled reproducibly. These cells displayed a biphasic uptake of $\mathrm{Mn}^{2+}$ (Fig. 1). First, $\mathrm{Mn}^{2+}$ was rapidly bound during the initial $10 \mathrm{~min}$ after the addition of the cation. This initial binding of the metal to the anionic sites of the fungal cell wall still occurred at $4{ }^{\circ} \mathrm{C}$ and reached about $0.8 \pm 0.2 \%$ of the total radioactivity in the experiments. However, although DPN was markedly inhibitory (Fig. 1), neither KCN nor sodium arsenate (both $10 \mathrm{~mm}$ ) inhibited the second phase of $\mathrm{Mn}^{2+}$ uptake in growing mycelia (data not shown). The failure to observe inhibition by $\mathrm{KCN}$ or sodium arsenate under these experimental conditions might be explained by the rather acid $\mathrm{pH}$ of the production medium ( 3.8 at the beginning and falling to even lower values). However, $\mathrm{KCN}$ (10 mM) was able to inhibit $\mathrm{Mn}^{2+}$ uptake at pH 5.6. When the specificity of $\mathrm{Mn}^{2+}$ transport was studied in the presence of a $10^{5}$ molar excess of competing cations ${ }^{54} \mathrm{Mn}^{2+}$ uptake was unaffected by $\mathrm{Mg}^{2+}$ and $\mathrm{Ca}^{2+}$, but more or less suppressed by $\mathrm{Cd}^{2+}, \mathrm{Cu}^{2+}$, unlabelled $\mathrm{Mn}^{2+}$ and $\mathrm{Zn}^{2+}($ Table 1). Oxygen uptake measurements revealed no toxicity of the competing cations, although $\mathrm{Cd}^{2+}$ and $\mathrm{Co}^{2+}$ produced a slight inhibition of respiration (less than $20 \%$ compared with the control) when the single chloride salts were added at a concentration of $1 \mathrm{~mm}$. 




Fig. 2

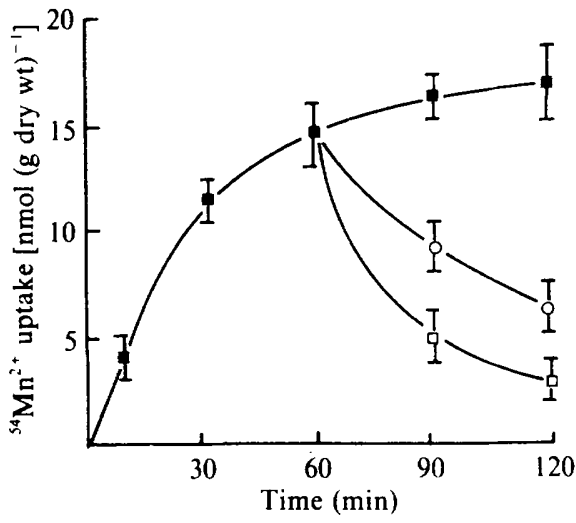

Fig. 3

Fig. 2. Effects of inhibitors on $\mathrm{Mn}^{2+}$ uptake in resting mycelia of $A$. niger. The data in the graph represent values corrected for unspecific binding. $\square, \mathrm{Mn}^{2+}$ uptake without inhibitory factors; $\bigcirc$, uptake in the absence of sucrose; $O$, uptake in the presence of sucrose under nitrogen gassing; $\square$. uptake in the absence of sucrose and with the addition of $200 \mu \mathrm{M}$-antimycin $\mathrm{A} ; A$, uptake in the presence of $0.1 \% \mathrm{w} / \mathrm{v}$ myxothiazol. The values in the curve for uptake without inhibitory factors represent the mean \pm SE for 16 experiments (for clarity error bars have been omitted from the curves which show inhibition of uptake).

Fig. 3. Effect of substances that alter membrane integrity on $\mathrm{Mn}^{2+}$ uptake. Uptake of $\mathrm{Mn}^{2+}$ at the $\mathrm{pH}$ optimum (pH 5.6) as control, ( $\square$ ). Either $0.5 \mathrm{M}$-toluene $(\square)$ or $5 \mathrm{M}$-ether $(O)$ was added after $1 \mathrm{~h}$ and the efflux of $\mathrm{Mn}^{2+}$ after this addition was measured. Values shown are the mean range of two experiments.

The uptake kinetics were determined from the linear rates of uptake over $10 \mathrm{~min}$ from $\mathrm{Mn}^{2+}$ concentrations in the range of 0.5 to $5.0 \mu \mathrm{M}$. The mean data of three separate experiments were plotted by the Lineweaver-Burk method, and the resultant straight line was fitted by the leastsquares method. The intercepts on the $y$ - and $x$-axes gave estimates of the maximal rate of transport, $V_{\max }$, and apparent half-saturation constant, $K_{t}$, respectively. The degree of uncertainty in these estimates was quantified by calculating the standard error of the estimates,

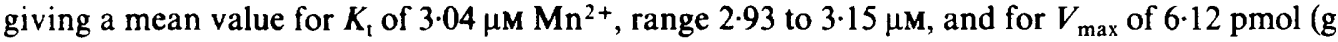
dry $w)^{-1} \mathrm{~min}^{-1}$, range 5.63 to $6.61 \mathrm{pmol}(\mathrm{g} \text { dry } \mathrm{wt})^{-1} \mathrm{~min}^{-1}$.

\section{$\mathrm{Mn}^{2+}$ uptake by resting mycelia}

$\mathrm{Mn}^{2+}$ uptake by $A$. niger was highly dependent upon the $\mathrm{pH}$ of the suspending medium, as was shown with washed mycelia resuspended in the buffers of Good et al. (1966), which have negligible metal-complexing capacity. ${ }^{54} \mathrm{Mn}^{2+}$ uptake was optimal between $\mathrm{pH} 5.6$ and 5.9 and reduced to about $40 \%$ and $15 \%$ at $\mathrm{pH} 7.5$ and 3.8 respectively. All further experiments with resting mycelia were done at $\mathrm{pH} 5 \cdot 6$, which resulted in ${ }^{54} \mathrm{Mn}^{2+}$ uptake after $2 \mathrm{~h}$ amounting to about $90 \%$ of the total radioactivity added, compared with $15 \%$ uptake observed with growing mycelia at $\mathrm{pH} 3.8$. With resting mycelia, binding of ${ }^{54} \mathrm{Mn}^{2+}$ to the cell surface was low $(1 \cdot 3 \pm 0.5 \%$ of total radioactivity in the experiment $)$ in the presence of sucrose and equalled that in assays with growing mycelia, but increased nearly fivefold when sucrose was omitted.

The energy-dependence of ${ }^{54} \mathrm{Mn}^{2+}$ uptake in $A$. niger observed previously with growing mycelia was further substantiated by results from experiments with metabolic inhibition of resting mycelia (Fig. 2). Compared to the control, anaerobic conditions established by gassing with nitrogen reduced uptake to $7 \%$ and omission of sucrose reduced it to $14 \%$. Addition of myxothiazol $\left(2 \mathrm{mg} \mathrm{ml}^{-1}\right)$ suppressed ${ }^{54} \mathrm{Mn}^{2+}$ uptake to $14 \%$, and complete inhibition was observed by the omission of sucrose and the addition of $200 \mu \mathrm{M}$-antimycin $\mathrm{A}$.

Since carrier-mediated transport systems require intact membranes as well as a functional 'permease' for substrate translocation we examined the effect of substances which alter membrane integrity. Treatment with toluene or diethyl ether released most of the recently translocated ${ }^{54} \mathrm{Mn}^{2+}$ from preloaded mycelia of $A$. niger (Fig. 3). 
The effect of bivalent cations on ${ }^{54} \mathrm{Mn}^{2+}$ uptake was also studied with resting mycelia (Table 1). Uptake was unaffected by a 5000-fold molar excess of $\mathrm{Mg}^{2+}$ and $\mathrm{Ca}^{2+}$. Strong inhibition was observed by $\mathrm{Zn}^{2+}, \mathrm{Cu}^{2+}, \mathrm{Cd}^{2+}$ and unlabelled $\mathrm{Mn}^{2+}$, and moderate inhibition by $\mathrm{Co}^{2+}, \mathrm{Ni}^{2+}$ and $\mathrm{Fe}^{2+}$.

\section{DISCUSSION}

The paucity of information relating to metal ion uptake of filamentous fungi partly arises from problems associated with mycelial growth. The energy-dependent $\mathbf{M n}^{2+}$-influx system demonstrated for $A$. niger is the first $\mathrm{Mn}^{2+}$-transport system known so far for filamentous fungi (Gadd, 1986), but can be compared with that recently described by Parkin \& Ross (1986) for the yeast $C$. utilis.

As has been shown in other papers on metal ion uptake a fast, but limited adsorption preceded the energy-dependent $\mathrm{Mn}^{2+}$ uptake in $A$. niger. The very low adsorption values in our experiments with growing mycelia (about $1 \%$ only) were probably due to the presence of $\mathrm{Mg}^{2+}$ in the growth medium which had preferably saturated the anionic sites on the fungal cell surface able to bind $\mathrm{Mn}^{2+}$. As the resting mycelium of $A$. niger adsorbed only limited amounts of $\mathrm{Mn}^{2+}$ on its surface during the uptake assays in MES buffer too, either $\mathrm{Mn}^{2+}$ appears to behave differently from other cations such as copper or the application of $\mathrm{Mn}^{2+}$-depleted cells from the early exponential phase of growth and the presence of very high amounts of sucrose $(14 \%)$ favoured uptake. Obviously due to masking of a low influx by adsorption, copper uptake could not be demonstrated with resting mycelium of $A$. niger (Townsley \& Ross, 1986) although MES buffer was used as in this study. Such difficulties, which arise from high binding of the cation to be tested, might be circumvented by protoplasting as was shown in copper uptake studies on Penicillium ochro-chloron (Gadd \& White, 1985).

The energy dependence of $\mathrm{Mn}^{2+}$ uptake by $A$. niger was shown by its sensitivity to low temperature and to the absence of oxygen or sucrose, and also well as by its sensitivity to both the uncoupling agent DNP and to the respiration inhibitor $\mathrm{KCN}$. A branched respiration chain seems to be present in $A$. niger as Kubicek et al. (1980) observed a salicyl hydroxamic acidsensitive bypass of respiration (Edwards \& $\mathrm{K}$ wiecinski, 1973) during the late trophophase in strain B 60 . In this paper myxothiazol, which has been identified as an inhibitor of fungal respiration (Gerth et al., 1980), caused a strong inhibition of $\mathrm{Mn}^{2+}$ influx in $A$. niger ATCC 11414. Myxothiazol, like other $\beta$-methoxyacrylates, has been classified as a group-I inhibitor of the mitochondrial $b c_{1}$ complex (Jagow \& Link, 1986) which blocks reduction of the iron-sulphur centre (cytochrome $c_{1}$ ) and of cytochrome $b$ via the $\mathrm{Q}_{0}$ site. The residual uptake of $\mathrm{Mn}^{2+}$ in the presence of a comparatively high concentration of myxothiazol $\left(2 \mathrm{mg} \mathrm{ml}^{-1}\right)$ may be explained by the observation that group-I inhibitors of the mitochondrial $b c_{1}$ complex permit reduction of cytochrome $b$ in a group-III inhibitor sensitive pathway by reversed electron flow through the $b_{\mathrm{b}}$ centre (Jagow \& Link, 1986). However, $\mathrm{Mn}^{2+}$ influx in A. niger was fully suppressed by combining the action of a group-III inhibitor (antimycin A) with deprivation of energy supply through omission of sucrose.

We have not yet studied the possibility of an energy-linked system for $\mathrm{Mn}^{2+}$ efflux in A. niger, which has been described in bacteria (Schmid \& Auling, 1987) and yeasts (Nieuwenhuis et al., 1981; Parkin \& Ross, 1986). However, as treatment of preloaded cells of $A$. niger for disintegration of membranes by toluene or diethyl ether (Jackson \& De Moss, 1965; Vosberg \& Hoffmann-Berling, 1971; Failla et al., 1976) gave rise to substantial efflux, only a small portion of the recently translocated $\mathrm{Mn}^{2+}$ seems to be bound in $A$. niger. This finding contrasts the situation in $S$. cerevisiae where only one-fourth of the accumulated $\mathrm{Mn}^{2+}$ is left osmotically free due to sequestering in polyphosphates within the vacuoles (Okorokov et al., 1977).

$\mathrm{Mn}^{2+}$ uptake, at the concentrations studied here, appeared to be via a highly specific mechanism, unlike the low-affinity divalent cation transporter previously observed in $S$. cerevisiae (Borst-Pauwels, 1981). As $\mathrm{Mn}^{2+}$ uptake was largely unaffected by a $10^{5}$ molar excess of both $\mathrm{Mg}^{2+}$ and $\mathrm{Ca}^{2+}$, the degree of cation specificity is in the range of that reported for $\mathrm{Mn}^{2+}$ transport in Escherichia coli (Silver et al., 1970) and greater than that observed for $\mathrm{Mn}^{2+}$ 
transport in C. utilis (Parkin \& Ross, 1986). The cation competition experiments with resting mycelia indicated that the high-affinity $\mathrm{Mn}^{2+}$ transport in $A$. niger was inhibited by $\mathrm{Cd}^{2+}, \mathrm{Zn}^{2+}$ and $\mathrm{Cu}^{2+}$ to the same extent. $\mathrm{Cd}^{2+}$ inhibition of high-affinity $\mathrm{Mn}^{2+}$ uptake seems to be a common feature of bacterial systems (Tynecka et al., 1981; Archibald \& Duong, 1984; Laddaga et al., 1985; Schmid \& Auling, 1987). $\mathrm{Mn}^{2+}$ transport in C. utilis is competitively inhibited by $\mathrm{Zn}^{2+}$ with an inhibitory constant greater than $K_{\mathrm{t}}$ for $\mathrm{Mn}^{2+}$ (Parkin \& Ross, 1986) and $\mathrm{Cu}^{2+}$ inhibits $\mathrm{Mn}^{2+}$ uptake in the diatom Thallasiosira (Sunda \& Huntsman, 1983). Addition of $\mathrm{Cu}^{2+}$ can be used to antagonize contaminations of $\mathrm{Mn}^{2+}$, which are deleterious in citric acid fermentations with $A$. niger (Kubicek \& Röhr, 1986). Our data indicate that this antagonism is due to competition for uptake by a 'micronutrient' transport system.

The kinetic data obtained for $\mathrm{Mn}^{2+}$ transport with growing mycelia of $A$. niger characterize this system as a 'micronutrient' transport system which is still rapid under conditions of citric acid fermentation, although not working at optimum $\mathrm{pH}$. Comparison of these data with those reported by Parkin \& Ross (1986) for the $\mathrm{Mn}^{2+}$ transport of $C$. utilis reveal similar velocity, but lower affinity. However, the affinity constant is comparable with those reported for the $\mathrm{Zn}^{2+}$ micronutrient systems of $C$. utilis and Aspergillus parasiticus (Failla et al., 1976; Failla \& Niehaus, 1986).

Thus in conclusion, there exists a $\mathrm{Mn}^{2+}$ transport in $A$. niger which is energy-dependent, substrate-specific and of high affinity. This system is easily detected at submicromolar concentrations of the metal using manganese-depleted cells which are able to produce citric acid.

We wish to thank Dr W. Ahrens for introducing us to the citric acid fermentation and Dr G. M. Gadd for critical reading of the manuscript. This work was supported in part by a grant from the Joh. A. Benckiser GmbH, Ludwigshafen, FRG. We thank I. Reupke for technical assistance and B. Georgi from the Niederächsisches Institut für Radioökologie, Hannover, FRG, for providing facilities for counting ${ }^{54} \mathrm{Mn}^{2+}$ as well as instructing us in their use.

\section{REFERENCES}

ARCHIbald, F. S. (1986). Manganese: its acquisition by and function in the lactic acid bacteria. $C R C$ Critical Reviews in Microbiology 13, 63-109.

ARChibalD, F. S. \& DuONG, M.-N. (1984). Manganese acquisition by Lactobacillus plantarum. Journal of Bacteriology 158, 1-8.

AULING, G. (1983). The effect of manganese limitation on DNA precursor biosynthesis during nucleotide fermentation with Brevibacterium ammoniagenes and Micrococcus luteus. European Journal of Applied Microbiology and Biotechnology 18, 229-235.

BORST-PAUWELS, G. W. F. H. (1981). Ion transport in yeast. Biochimica et biophysica acta 650, 88-127.

Clark, D. S., Ito, K. \& Horitsu, H. (1966). Effect of manganese and other heavy metals on submerged citric acid fermentation with molasses. Biotechnology and Bioengineering 3, 465-471.

EDWARDS, D. L. \& Kwiecinski, F. (1973). Altered mitochondrial respiration in a chromosomal mutant of Neurospora crassa. Journal of Bacteriology 116, 610-618

Failla, L. J. \& Niehaus, W. G. (1986). Regulation of $\mathrm{Zn}^{2+}$ uptake and versicolorin $A$ synthesis in a mutant strain of Aspergillus parasiticus. Experimental Mycology 10, 35-41.

Failla, M. L., Benedict, C. D. \& Weinberg, E. D. (1976). Accumulation and storage of $\mathrm{Zn}^{2+}$ by Candida utilis. Journal of General Microbiology 94, 23-26.
GADD, G. M. (1986). Fungal responses towards heavy metals. In Microbes in Extreme Environments, pp. 83110. Edited by R. A. Herbert \& G. A. Codd. London: Academic Press.

GADD, G. M. \& WhITE, C. (1985). Copper uptake by Penicillium ochro-chloron: influence of $\mathrm{pH}$ on toxicity and demonstration of energy-dependent copper influx using protoplasts. Journal of General Microbiology 131, 1875-1879.

Garraway, M. O. \& Evans, R. C. (1984). Fungal Nutrition and Physiology, 1st edn. New York: John Wiley.

Gerth, K., Irschik, H., Reichenbach, H. \& Trowitzsch, W. (1980). Myxothiazol, an antibiotic from Myxococcus fulvus (Myxobacteriales). I. Gel filtration, isolation, physico-chemical and biological properties. Journal of Antibiotics 33, 1474-1479.

GOOD, N. E., WINGeT, G. D., WINTER, W., Connolly, T. N., Izawa, S. \& Singh, R. M. M. (1966). Hydrogen ion buffers for biological research. Biochemistry 5, 467-477.

Hockertz, S., Plönzig, J. \& Auling, G. (1987). Impairment of DNA formation is an early event in Aspergillus niger under manganese starvation. Applied Microbiology and Biotechnology 25, 590593.

JACKSON, R. W. \& DE Moss, J. A. (1965). Effects of toluene on Escherichia coli. Journal of Bacteriology 90 , 1420-1425 
JAGow, V. G. \& Link, T. A. (1986). Use of specific inhibitors on the mitochondrial $b c_{1}$ complex. Methods in Enzymology 126, 253-271.

KubiceK, C. P. \& RöHR, M. (1986). Citric acid fermentation. CRC Critical Reviews in Biotechnology 3, 331-373.

Kubicek, C. P., Zehentgruber, O., El-Kalak, H. \& ROHR, M. (1980). Regulation of citric acid production by oxygen : effect of dissolved oxygen tension on adenylate levels and respiration in Aspergillus niger. European Journal of Applied Microbiology and Biotechnology 9, 101-115.

LAdDAGA, R. A., Bessen, R. \& Silver, S. (1985). Cadmium-resistant mutant of Bacillus 168 with reduced cadmium transport. Journal of Bacteriology 162, 1106-1110.

Mohan, P. M., Rudra, M. P. P. \& Sastry, K. S. (1984). Nickel transport in nickel-resistant strains of Neurospora crassa. Current Microbiology 10, 125-128.

NieuWenhuis, B. J. W., Weisers, C. A. G. M. \& Borst-Pauwels, G. W. F. H. (1981). Uptake and accumulation of $\mathrm{Mn}^{2+}$ and $\mathrm{Sr}^{2+}$ in Saccharomyces cerevisiae. Biochimica et biophysica acta 649, 83-88.

OKoRoKov, L. A., LichKo, L. P., KADOMTSEVA, V. M., Kholodenko, V. P., Titovski, V. T. \& KulaeV, I. S. (1977). Energy-dependent transport into yeast cells and distribution of accumulated ions. European Journal of Biochemistry 75, 373-377.

PARKIN, M. \& Ross, I. S. (1985). Uptake of copper and manganese by the yeast Candida utilis. Microbios Letters 29, 115-120.

PARKIN, M. \& Ross, I. S. (1986). The specific uptake of manganese in the yeast Candida utilis. Journal of General Microbiology 132, 2155-2160.

Paton, W. H. N. \& Budd, K. (1972). Zinc uptake in Neocosmospora vasinfecta. Journal of General Microbiology 72, 173-184.

Plönzig, J. \& Auling, G. (1987). Manganese deficiency impairs ribonucleotide reduction but not
DNA replication in Arthrobacter species. Archives of Microbiology 146, 396 401.

SCHMID, J. \& AULING, G. (1987). Manganese transport in Brevibacterium ammoniagenes ATCC 6872. Journal of Bacteriology 169, 3385-3387.

Shu, P. \& Johnson, M. J. (1948). Citric acid production by submerged fermentation with Aspergillus niger. Industrial and Engineering Chemistry International edition 40, 1202-1205.

SIL VER, S. (1978). Transport of cations and anions. In Bacterial Transport, pp. 222-324. Edited by B. P. Rosen. New York: Marcel Dekker.

SILVER, S. \& JASPER, P. (1977). Manganese transport in microorganisms. In Microorganisms and Minerals, pp. 105-149. Edited by E. D. Weinberg. New York: Marcel Dekker.

SIL Ver, S., JOHNSEINE, P. \& KING, K. (1970). Manganese active transport in Escherichia coli. Journal of Bacteriology 104, 1299-1306.

Sunda, W. G. \& Huntsman, S. A. (1983). Effect of competitive interactions between manganese and copper on cellular manganese and growth in estuarine and oceanic species of the diatom Thalassiosira. Limnology and Oceanography 28, 924-934.

TownSLEY, C. C. \& Ross, I. S. (1986). Copper uptake in Aspergillus niger during batch growth and in nongrowing mycelial suspensions. Experimental $M y$ cology 10, 281-288.

TYNECKA, Z., Gos, Z. \& ZAJAC, J. (1981). Reduced cadmium transport by resistance plasmid in Staphylococcus aureus. Journal of Bacteriology 147, 305-312.

VosberG, H.-P. \& Hoffmann-Berling, H. (1971). DNA synthesis in nucleotide-permeable Escherichia coli cells. I. Preparation and properties of ethertreated cells. Journal of Molecular Biology 58, 739753.

Williams, R. J. P. (1982). Free manganese(II) and iron(II) cations can act as intracellular controls. FEBS Letters 140, 3-10. 